\title{
Engkerebai Kayoh (Psychotria malayana) Among Dye Plants of Dayak Iban People in Sungai Utik Village of Kapuas Hulu, West Kalimantan, Indonesia
}

\author{
Wahdina ${ }^{1 *}$ Dede Setiadi ${ }^{1}$ Y Purwanto ${ }^{2}$ Ibnul Qayim ${ }^{1}$ \\ ${ }^{1}$ Dept. of Biology, Faculty of Mathematics and Science (FMIPA), SPS IPB University, Bogor, Indonesia \\ ${ }^{2}$ Man and Biosphere, Indonesian Institute of Science, Bogor, Indonesia \\ *Corresponding author. Email: wahdina_bot17@apps.ipb.ac.id
}

\begin{abstract}
Kalimantan is one of the largest islands in Indonesia, rich in useful plants. People's local knowledge in managing useful plants is valuable. Sungai Utik Village was one of the villages in Kalimantan where Dayak Iban people living near the forest and was one of the ecotourism destinations in Kapuas Hulu, West Kalimantan. They have their customary forest where they can collect and manage many useful plants for their own subsistent. Most of these people live as farmers and weavers, and they still use the traditional way to dye their products. This writing aimed to review the engkerebai kayoh plant as one of the primaries dye plants used by Dayak Iban people in Sungai Utik Village of Kapuas Hulu District, West Kalimantan, Indonesia. A semi-structured interview was performed to find out the Dayak Iban's local knowledge about the role of engkerebai kayoh as a dye plant in Sungai Utik Village. A simple laboratory method combined with a literature study to reveal the plant content responsible for the plant's red dye. There were six plants used by people in Sungai Utik Village to make red dye, and six plants to make black dye for their weaving. Among the dye plants they used, the engkerebai kayoh plant was the primary dye plant, seen by its quality, intensity, and exclusivity of Dayak Iban people's culture. A simple qualitative phytochemistry test showed that the engkerebai kayoh plant contained low alkaloid, saponin, terpenoid and phenolics, moderate flavonoid, and high tannin. This result explained the red color produced from engkerebai leaves was reddish-brown and not bright red.
\end{abstract}

Keywords: Ethnobotany, ICS, red dye, Dayak Iban people

\section{INTRODUCTION}

Kalimantan or Borneo is one of the largest islands in Indonesia with high biodiversity and precise endemicity. As one of the renewable resources, the plant species must be revealed more to manage their usage effectively and continue. The biggest threat of biodiversity loss in Kalimantan is deforestation and land-use conversion. In this last decade, an estimated 18.7 Mha of Borneo's oldgrowth forest were cleared. Approximately 7.0 Mha (76\%) of the total area of industrial plantations in 2015 (9.2 Mha), were old-growth forests in 1973, of which 4.5 Mha had been planted rapidly, i.e. within five years of forest clearance. Rapid conversion of forest to industrial plantations represents a growing cause of deforestation in Indonesian Borneo [1]. Conservation value decreased and the future of the forest became uncertain. Poverty became a threat to the people living in and managing the forest because there was an alternative forest land-use conversion to more profitable economically, for example, monoculture plantation or farming. But monoculture plantation or farming on the other side can disturb the forest existence and decrease biodiversity. For the people stand in managing forest, it is a big challenge to still have the profit in the effort to maintain the forest healthy and its biodiversity [2].

Local people's knowledge in managing forest, especially a customary forest, and using the vegetation optimally and sustainably is a valuable thing and must be revealed and considered as an alternative in managing forest and also maintaining the important 
biodiversity value. With this awareness, then the biodiversity existence is precisely a solution for the people, and also for Kalimantan's sustainable biodiversity.

Dye plants as a component of the forest vegetation was a unique part of the forest biodiversity, because these plants used by people living around the forest, and many of the species were non-wood forest products and collected regularly without damage to the forest vegetation. Engkerebai kayoh (Psychotria malayana) was one of the dye plants used by Dayak Iban people of Sungai Utik Village, Kapuas Hulu. We want to find out how important the species as dye plants for these people, do they have specific local knowledge in managing this species sustainably, and how far was the scientific proof in the local knowledge they have.

\section{MATERIALS AND METHODS}

\subsection{Location}

The research took place in Sungai Utik Hamlet, Kapuas Hulu Regency, West Kalimantan, Indonesia. Sungai Utik hamlet was one of the ecotourism destinations in Kapuas Hulu Regency where the Dayak Iban people live. These people of Sungai Utik hamlet live as farmers, weavers, and plaiters and manage a customary forest to fulfill their subsistence.

\subsection{Ethnobotanical Study}

The information about the dye plants used by people was revealed using a semi-structured interview and walk-in wood interview. The plant samples were collected, and photographs and herbarium documentation were made for further determination. The respondents were chosen using the Snowball sampling technique. All the respondents were Dayak Iban people living in Sungai Utik Village who knows and have ever and/or still using traditional dyeing in weaving and craft-plaiting. Ethnobotanical data analysis was using Index of Cultural Significance (ICS) modified from [3] and [4].

\subsection{Phytochemical Test}

A simple phytochemical test was performed using methods from [5] to find out the qualitative phytochemical content of engkerebai kayoh leaves. The engkerebai kayoh leaves were collected from Sungai Utik hamlet, Kapuas Hulu Regency, West Kalimantan Province, Indonesia. They were identified by the authors, based on people's local knowledge and confirmed by the key of determination for P. malayana (. Plant parts taken are leaves, which were then dried until a constant weight was obtained. The simple phytochemistry test was performed to reveal the alkaloid, flavonoid, saponin, terpenoid, steroid, tannin, and phenolic contents of the plant parts used. The test was performed in the Chemistry Research and Biotechnology Laboratory of Maths and Natural Sciences Faculty, Tanjungpura University, Pontianak, Indonesia.

\section{RESULT AND DISCUSSION}

There were six plants used by people in Sungai Utik Village to make red dye, and six plants to make black dye for their weaving (Table 1). Dayak Iban people in Sungai Utik Village recognize three colors for their cultural weaving, those colors were white as the base color of the plain yarn, red, and black. The red color was commonly the main color in Dayak Iban's traditional wearing, while the black and the white color were the complementary ornaments.

Among the dye plants they used, the engkerebai kayoh plant was the primary dye plant, seen by its quality, intensity, and exclusivity of Dayak Iban people's culture (Table 2). All of the Dayak Iban weaver and crafter in Sungai Utik Village know engkerebai kayoh well as a dye plant, and they get the knowledge from their old generations and ancestors. Engkerebai kayoh made red dye on cotton yarn. The red color was considered to be the most important color for Dayak Iban people in their ritual culture. Engkerebai kayoh was found abundant in the wild as an understorey plant in the Menua customary forest and the forested area and also the rubber plantation around rumah betang. The people said that the plant grows easily, and grow more branch if the main stem cut. The fruit and seed were spread by birds. Three species had a maximum score of ICS: engkerebai kayoh, engkerebai laut, and rengat kikat (Table 2). Engkerebai kayoh was considered as the most important because every respondent knew the plant and mentioned it mostly the first time as a dye plant. 

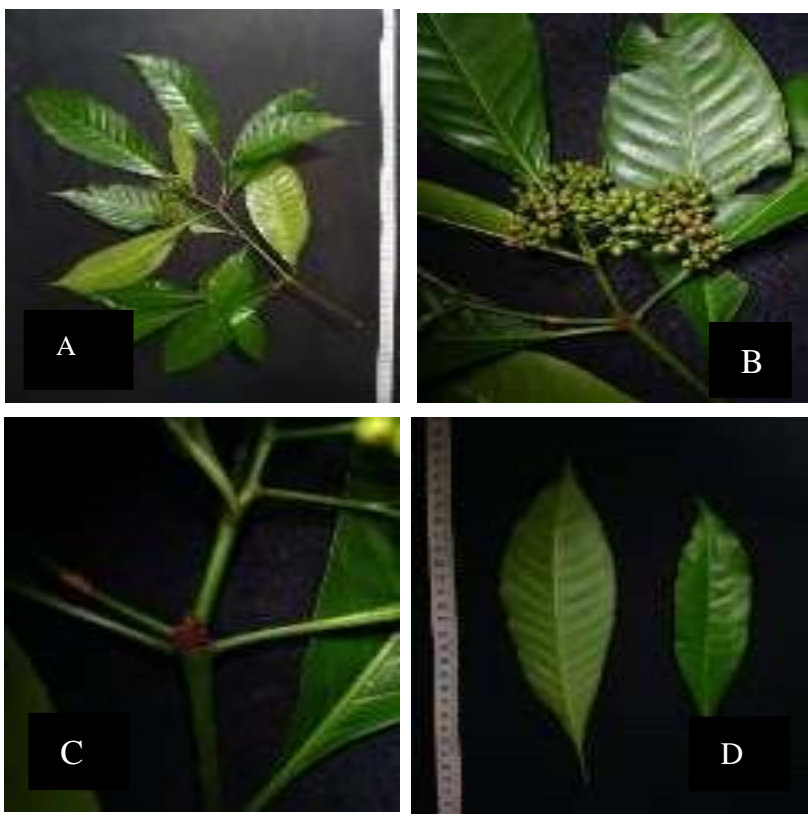

Figure 1. The engkerebai kayoh plant (Psychotria malayana), red dye plant used by Dayak Iban people in Sungai Utik Hamlet, Kapuas Hulu, West Kalimantan. A, A branch with leaves and a bunch of fruits, B. Details of fruits, C. A closer look at the branch showing deccusate leaves arrangement typical in Rubiaceae family, and interpetiolar stipule, D. Leaf adaxial and abaxial showing midrib and obvious lateral venation, the lateral vein were more than 9 pairs.

Table 1. Dye plant species used by Dayak Iban people in Sungai Utik Village, Kapuas Hulu, Kalimantan Barat

\begin{tabular}{l|l|l|l|l}
\hline \multicolumn{1}{c|}{ Local name } & \multicolumn{1}{|c|}{ Botanical name } & Family & $\begin{array}{l}\text { Part of the } \\
\text { plant } \\
\text { used }\end{array}$ & $\begin{array}{l}\text { Color } \\
\text { produced }\end{array}$ \\
\hline Beting & Litsea glomerata & Lauraceae & Bark & Red \\
Engkerebai kayoh & Psychotria malayana & Rubiaceae & Leaf & Red \\
Engkerebai laut & Peristrophe bivalvis & Acanthaceae & Leaf & Red \\
Jangau & Aporosa sp & Phyllantaceae & Bark & Red \\
Engkudu & Morinda citrifolia & Rubiaceae & Root & Red \\
Jambu melaban & Psidium guajava & Myrtaceae & Leaf & Red \\
Tebelian & Eusideroxylon zwageri & Lauraceae & Wood & Red \\
Bungkang & Syzygium polyanthum & Myrtaceae & Bark & Black \\
Menuang & Not identified yet & Not known & Bark & Black \\
Manyam & Glochidion lutescens & Phyllantaceae & Leaf & Black \\
Rengat kikat & Clerodendrum laevifolium & Lamiaceae & Leaf & Black \\
Rengat padi & Indigofera arrecta & Fabaceae & Leaf & Black \\
Sibau & Nephelium cuspidatum & Sapindaceae & Leaf, husk & Black \\
\hline
\end{tabular}


Engkerebai kayoh was the first plant mentioned and known well by every respondent as a dye plant producing red color (Figure 2). There were a few respondents who state that the red color made of engkerebai kayoh was not bright, but they still willingly use it. This plant was used by both the weaver and the craft plaiter.

Table 2. The Index of Cultural Significance (ICS) score for the dye plants used by Dayak Iban people in Sungai Utik Hamlet of Kapuas Hulu, West Kalimantan
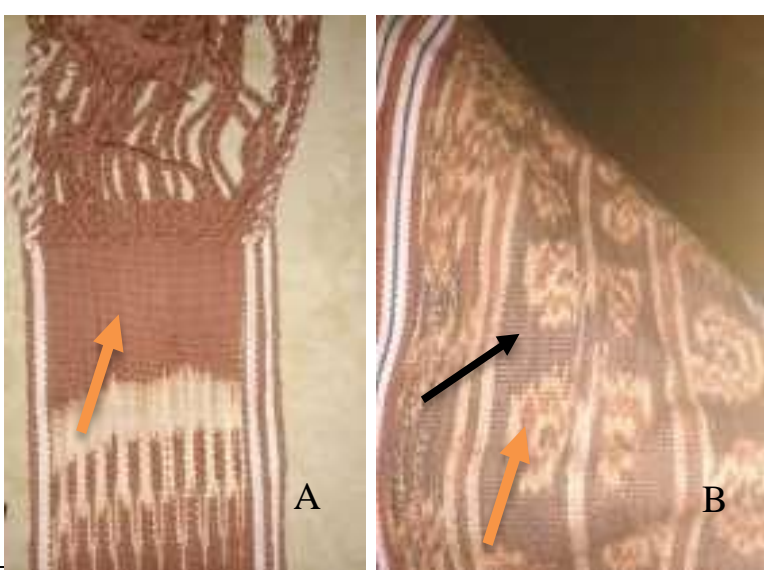

\begin{tabular}{l|ll|ll}
\hline Local Name & Intensity & Quality & Exclusivity & ICS \\
\hline Beting & 3 & 2 & 2 & 7 \\
$\begin{array}{l}\text { Engkerebai } \\
\text { kayoh }\end{array}$ & 4 & 3 & 2 & 9 \\
Engkerebai laut & 4 & 3 & 2 & 9 \\
Jangau & 4 & 2 & 2 & 8 \\
Engkudu & 3 & 3 & 2 & 8 \\
Jambu melaban & 1 & 1 & 0.5 & 2.5 \\
Tebelian & 2 & 2 & 1 & 5 \\
Bungkang & 2 & 2 & 1 & 5 \\
Menuang & 3 & 3 & 2 & 8 \\
Manyam & 3 & 3 & 2 & 8 \\
Rengat kikat & 4 & 3 & 2 & 9 \\
Rengat padi & 3 & 3 & 2 & 8
\end{tabular}

Engkerebai kayoh as a red dye plant was used alone without adding other dye plants. The dye was extracted by boiling water. The lime added in the dyeing process was used to lock the color substance to the cotton fiber. The Dayak Iban people make the lime they used by burning keong's shell, kinds of mollusks gathered from the river.

A simple qualitative phytochemistry test showed that the engkerebai kayoh plant contained low alkaloid, saponin, terpenoid and phenolics, moderate flavonoid, and high tannin. This result explained red color produced from engkerebai leaves was reddishbrown and not bright red.

A summary of much research was made and the natural dye was grouped based on the chemical structure and the color produced (6). There was the indigoid class with blue-purple color, pyridine class with bright yellow color, the carotenoid or tetraterpenoid with yellow, orange and red color, quinoid class with yellow to red color; the flavonoid class with pale yellow to dark yellow, orange, red to blue and purple color, include anthocyanins, dihydropyran class with red to orange color.
Figure 2. The red color of engkerebai kayoh, A. Dyeing with only engkerebai kayoh leaves make the two-color combination of red and white, B. The color of engkerebai kayoh leaves (brownish-red, orange arrow) and rengat kikat leaves (the darkest brown color closer to black color, black arrow) were made by double steps in dyeing yarn, the first step with engkerebai kayoh, and the next dyeing step using rengat kikat leaves.

There was also the betalain class specific to the plants of ordo Caryophyllales with yellow and purple color; besides the tannin class with yellow, brown, grey, and black color (6). The tannin group was separated from other color- produce-chemical groups because of the specific ability to react with protein fiber and conserved the material and protect it against putrefaction (7). According to (6), the red color of the engkerebai kayoh leaves extract used for dyeing was not the purple- indigoid nor bright yellow pyridine nor betalain. It was suspected as carotenoid or tetraterpenoid, or quinoid, or flavonoid, or dihydropyran, or tannin. In engkerebai kayoh leaves extracted with water, the people get the red color of flavonoid, mixed with chlorophyll and tannin. In hot water extract, the chlorophyll washed easily, but the flavonoid, phenolics, and tannin mixed producing red dye. The more the engkerebai leaves used, the more vivid the red color produced, but the red hue is about

Most secondary metabolite found in Rubiaceae was iridoids, triterpenes, alkaloids, and anthraquinones, and there were differences between genus and species (8). (9) try to find out the alkaloid contents in Psychotria malayana of Lombok and found specific alkaloid hodgknsine as a major alkaloid in P. malayana. the same (Figure 2). 


\section{CONCLUSION}

There were seven plants used by people in Sungai Utik Village to make red dye, and six plants are used to make black dye for their weaving. Among the dye plants they used, the engkerebai kayoh plant was the primary dye plant, seen by its quality, intensity, and exclusivity of Dayak Iban people's culture. A simple qualitative phytochemistry test showed that the engkerebai kayoh plant contained low alkaloid, saponin, terpenoid and phenolics, moderate flavonoid, and high tannin. This result explained red color produced from engkerebai leaves was reddishbrown and not bright red.

\section{ACKNOWLEDGMENT}

This study was supported by Hibah Penelitian Disertasi Doktor from the Ministry of Research Technology and Higher Education/BRIN of Republik Indonesia 2020. Thank you very much and many regards to the Kapuas Hulu Government and the people of Sungai Utik Hamlet for the nice welcomes and assistance.

\section{REFERENCES}

[1] D.L.A. Gaveau, D. Sheil, Husnayaen, M.A. Salim, S. Arjasakusuma, M.Ancrenaz, P. Pacheco, E. Meijaard, Rapid conversions and avoided deforestation: examining four decades of industrial plantation expansion in Borneo. Scientific Reports 6 (2016) 32017. DOI:https://doi.org/10.1038/srep32017

[2] J.D. Langston, R.A. Riggs, Y. Sururi, T. Sunderland, M. Munawir. Estate crops more attractive than community forests in West Kalimantan, Indonesia. Land: 6 (12) (2017) 114. DOI: https://doi.org/10.3390/land6010012

[3] N.J. Turner, "The Importance of a Rose": Evaluating the Cultural Significance of Plants in Thompson and Lillooet Interior Salish, American Anthropologist, New Series 90 (2) (1988) 272-290.

[4] A.P. Dewi, N.S. Ariyanti, E.B. Walujo, Diversity of plants used for plaited crafts by the Dayak Iban-Désa in Kabupaten Sintang, Kalimantan Barat, Reinwardtia 15 (2) (2016) 67-79.

[5] J.B. Harborne, Metode Fitokimia, Penerbit ITB, 1987. [In Bahasa Indonesia]

[6] Mohd. Yusuf, Mohd. Shabbir, F. Mohammad, Natural colorants: historical, processing and sustainable prospects, Natural Products and
Bioprospecting 7 (2017) 123-145. DOI: https://doi.org/10.1007/s13659-017-0119-9.

[7] R.H.M.J. Lemmens, N. Wulijarni-Soetjipto. Plant Resources of South East Asia No. 3 Dye and Tannin-producing Plants, PROSEA, 1992.

[8] D. Martins, C.V. Nunez, Secondary metabolites from Rubiaceae species, Molecules 20 (2015) 13422-13495. DOI: https://doi.org/10.3390/molecules200713422

[9] S. Hadi, D. Asnawati, V.F. Ersalena, A. Azwari, K.P. Rahmawati, Characterization of alkaloids from the leaves of Psychotria malayana Jack of Lombok Island on the basis of Gas Chromatography-Mass Spectroscopy. The Journal of Pure and Applied Chemistry Research 3 (3) (2014) 108-113. 